FACTA UNIVERSITATIS

Series: Physical Education and Sport, Vol. 17, No 3, 2019, pp. 579 - 589

https://doi.org/10.22190/FUPES191016052S

Research article

\title{
EFFECTS OF AN EXERCISE PROGRAM ON THE COORDINATION AND EXPLOSIVE POWER OF UNIVERSITY DANCE STUDENTS
}

\author{
UDC 796.012.112
}

796.035:793.32

\author{
Dejan Stošićc ${ }^{1}$, Slavoljub Uzunović ${ }^{2}$, Saša Pantelićc ${ }^{2}$, \\ Saša Veličković ${ }^{2}$, Marko Đurović ${ }^{2}$, Danica Piršl ${ }^{2}$ \\ ${ }^{1}$ Faculty of Sport and Physical Education, University of Priština, Leposavić, Serbia \\ ${ }^{2}$ Faculty of Sport and Physical Education, University of Niš, Niš, Serbia
}

\begin{abstract}
The aim of this research is to determine the effects of a ten-week modern and recreational dance exercise program and trunk and leg muscle strengthening exercises on the coordination and explosive power of student-age female dancers. The total number of participants was 54, of which 27 made up the experimental group who participated in an experimental exercise program and 27 the control group. The experimental group performed Hip Hop and Dancehall dances and trunk and leg muscle strengthening exercises 3 times a week for 90 min each. The control group had no additional forms of exercise other than regular daily activities. The coordination of the participants was evaluated on the basis of six tests (Side Steps, 20 Steps forward Twirling a Baton, Skipping the Horizontal Jump Rope, Turning in 6 squares, Hand-Foot Drumming and Agility test with a Baton) and two tests for determining explosive power parameters (the squat jump and countermovement jump). Results showed statistical significance between the groups in 5 variables of coordination at the multivariate and univariate level ( $p<.05$, $p<.01$ ), and in both variables of explosive power at the univariate level ( $p<.05)$. A large and intermediate effect size of the experimental program was determined for 5 variables of coordination, and intermediate effect size for both variables of explosive power. The results of this study showed that a ten-week exercise program for recreational and modern dance and exercises for strengthening the muscles of the torso and legs have a positive effect on the changes in the parameters of coordination and explosive power in student-age female dancers.
\end{abstract}

Key words: Coordination, Explosive Power, Recreation, Modern Dances

Received October 16, 2019/ Accepted December 26, 2019

Corresponding author: Dejan Stošić

Faculty of Sport and Physical Education, University of Priština, Dositejeva bb, 38218 Leposavić, Serbia

Phone: + $3812883771 \cdot$ E-mail: dejan.stosic@pr.ac.rs 


\section{INTRODUCTION}

Each dance style engages a dancer's muscles differently, thus the development of appropriate motor skills and improvement of certain fitness components will depend on the type of dance (Pepper, 1984; Kirkendal \& Calabrese, 1983). A great deal of research has examined the motor skills of dancers and physiological demands of different dance styles (Jin et al., 2019; Rodrigues-Krause et al., 2014; Liiv et al., 2012; Macura, Pešić, ĐorđevićNikić, Stojiljković, \& Dabović, 2007; Wyon \& Redding, 2005). Most of this research was conducted on a sample of ballet dancers, contemporary dancers and sports dancers who had a longer dance experience, while a small number of studies covered modern dances that have become popular in recent decades, such as Hip Hop, Dancehall, etc., as well as the effects of those dances on those who engaged in these dances recreationally, rather than competitively.

Coordination is a complex ability necessary for the realization of virtually every motor operation, from the simplest to the most complex movements, and is necessary for the formation of a good motor foundation (Metikoš, Marković, Prot, \& Jukić, 2003), which makes its development very important for the general population. It is also considered the basis necessary for athletes to develop sport-specific techniques (Stošić, Uzunović, Kostić, Ljubojević, \& Marković, 2013), thus improving coordination skills is of great importance for athletes and competitors as well. Precisely because the development of coordination can bring various benefits to both athletes and the general population, it is important to plan and systematically implement activities that can influence its increase.

Muscle force indicates the ability of a muscle to cope with a load or force, while muscle power is defined as exerting force in the shortest possible time (Brown et al., 2007). Dancers need muscle force to master slow and controlled movements, as well as muscle power to perform jumps, acrobatic elements and other explosive movements. Although it is necessary for the performance of many dance elements, force and force training are not generally accepted in dance circles; mostly for fear that force parameters and muscle hypertrophy may adversely affect the aesthetic appearance of the dancer. Certain studies have proven that it is possible to increase power parameters without proportional changes in the muscle and impairment of the dancers' aesthetic appearance (Vetter \& Dorgo, 2009; Koutedakis \& Sharp, 2004). Such changes are possible due to the central nervous system adaptation and activation of more muscles and motor units (Slddlque, Rahman, Frazer, Howatson, \& Kidgell, 2019); however, subjective thinking about the negative effects of power training are still grounded in the dance world. Given that conventional dance training does not bring much benefit in improving power parameters (Rimmer, Jay, \& Plowman, 1994), there is a need to introduce additional exercises to provide adequate training stimulus, which will benefit both competitors and recreationists.

Dance is dominated by complex movements which require a high level of coordination of dancers, good speed and rhythmic ability, as well as the connection of complex motor tasks in space and time. Research has shown that professional dancers have better coordination stability which they achieve through neuromuscular control and perceptual sensitivity (Kiefer et al., 2011), as well as better sensorimotor synchronization of whole body movements (Jarvis, Smith, \& Kulig, 2014).

Dance is an activity that has always been present in people's lives, whether it is a sports or art, but the development of media and social networks has led people to take it as a form of fun physical exercise. The aim of this research is to determine the effects of a 
modern and recreational dance exercise program and trunk and leg muscle strengthening exercises on the coordination and explosive power of student-age female dancers.

The aim of this research is to determine the effects of a ten-week modern and recreational dance exercise program and trunk and leg muscle strengthening exercises on the coordination and explosive power of student-age female dancers.

\section{METHODS}

\section{Sample of female participants}

The sample consisted of female students from the University of Niš, aged 19-24. The basic criteria for inclusion in the experimental program were: that the participants were of good health status and did not suffer from any cardiovascular or respiratory disease, that they had not been included in any form of organized recreational or professional form of exercise over the last 6 months, that they were not in the rehabilitation or recovery process from any type of injury. The total number of participants was 54, of which 27 made up the experimental group - EG (height $165.4 \pm 5.81 \mathrm{~cm}$, mass $60.1 \pm 6.97 \mathrm{~kg}$ and BMI $22.01 \pm 2.34 \mathrm{~kg} / \mathrm{m}^{2}$ ) and 27 the control group - CG (height $166.3 \pm 6.09 \mathrm{~cm}$, mass $60.6 \pm 8.21 \mathrm{~kg}$ and BMI $22.1 \pm 2.36 \mathrm{~kg} / \mathrm{m}^{2}$ ). The $\mathrm{CG}$ had no additional forms of exercise other than regular daily activities.

\section{Sample of measuring instruments}

The coordination of the participants was evaluated on the basis of six tests, namely:

1. Side Steps (Metikoš, Prot, Hoffman, Pintar, \& Oreb, 1989);

2. 20 Steps forward Twirling a Batton (Kurelić, Momirović, Stojanović, Šturm, Radojević, \& Viskić-Štalec, 1975);

3. Skipping the Horizontal Jump Rope (Marčelja, Hošek, Viskić-Štalec, Horga, Gredelj, \& Metikoš, 1973);

4. Turning in 6 Squares (Kostić, 1995);

5. Hand-Foot Drumming (Hošek, Horga, Viskić-Štalec, Metikoš, Gredelj, \& Marčelja, 1973);

6. Agility Test with a Baton (Kurelić et al., 1975).

To estimate the explosive power parameters, the following tests were applied:

1. Squat Jump (SJ);

2. Countermovement Jump (CMJ).

Explosive power parameters were measured by Optojump (Perform Better Limited, UK). The parameter to be evaluated is the jump height of the female participants.

\section{The experimental exercise program}

The experimental program whose structure is shown in Table 1 involved the application of the dance elements of Hip Hop and Dancehall and exercises to strengthen the trunk and leg muscles for 10 weeks. The program was implemented 3 times a week for 90 minutes each. Each class had a three-part structure where, in the introductory part, mild warm-up exercises in the form of dance aerobics, dynamic warm-up and exercises for strengthening the muscles of the torso and legs were applied. The main part consisted of 
the dance elements of Hip Hop and Dancehall, which were rehearsed in the form of choreography on specific music, while in the final part stretching exercises were applied.

Exercises for strengthening the muscles of the legs and trunk during the first four weeks were aimed at raising the general level of strength and basic physical preparation. The organization of the exercises was based on the principle of the circuit exercising with one's own weight. The total volume of strength training was 15-25 sets, i.e., 1-3 exercises were applied to each muscle group. In order to maximize the metabolic effect of the exercise and to ensure that 15 to 20 regular repetitions are performed, the exercises were performed for 30 seconds. The rest time between exercises was 30-60 seconds. For the next four weeks, plyometric exercises consisting of jumps, hops, skips and other moderate intensity exercises were applied. The total number of contacts with the ground during the plyometric part of the training ranged from 90 to 140 contacts. The last two weeks multi-joint and isolation strengthening exercises, and plyometric exercises were combined.

Table 1 Structure of the experimental program

\begin{tabular}{llcc}
\hline & Experimental group & Control group \\
Frequency & 3x times a week & & - \\
Duration & 90 min & & - \\
Intensity & Maximal number of reps for $30 \mathrm{~s}$ & - \\
\hline Class structure & & Duration & \\
\hline Introductory part & Dance aerobic & $5 \mathrm{~min}$ & \\
& Dynamic warm up & $5 \mathrm{~min}$ & - \\
& Strength exercises & $15 \mathrm{~min}$ & - \\
Main part & Dance choreography & $50 \mathrm{~min}$ & \\
Final part & Stretching & $15 \mathrm{~min}$ & \\
\hline
\end{tabular}

\section{Statistical analysis}

All data were processed by the Statistical Package for Social Sciences software package (v17.0, SPSS Inc., Chicago, IL, USA). Basic descriptive statistical parameters were calculated for all the variables, and the results of the arithmetic means and standard deviation are presented in table form.

Statistically significant differences between the groups at the initial and final measurements were determined using a multivariate analysis of variance (MANOVA), while a univariate analysis of variance (ANOVA) was used to determine differences between the groups for each variable. Difference testing was performed by the F-test, and the significance level was expressed as $\mathrm{p}$.

The differences between the initial and final measurements of the EG and CG were determined by the t-test for the dependent samples, i.e., Effect Size. The criterion for determining the degree of the impact (Effect size) was: .01=small effect size; $.06=$ intermediate effect size; .14=large effect size (Cohen, 1988). 


\section{RESULTS}

Table 2 shows the basic statistical parameters for the experimental and control groups. Based on the presented data, it can be observed that the participants of the experimental group achieved better results on all the measured parameters for the evaluation of coordination and explosive power.

Table 2 Basic statistical parameters of the experimental (EG) and control group (CG)

\begin{tabular}{lrrrr}
\hline Variable & \multicolumn{2}{c}{ EG } & \multicolumn{2}{c}{ CG } \\
\cline { 2 - 5 } & \multicolumn{1}{c}{$\begin{array}{c}\text { Initial } \\
\text { Mean } \pm \text { SD) }\end{array}$} & $\begin{array}{c}\text { Final } \\
\text { (Mean } \pm \text { SD) }\end{array}$ & $\begin{array}{c}\text { Initial } \\
\text { (Mean } \pm \text { SD) }\end{array}$ & $\begin{array}{c}\text { Final } \\
\text { (Mean } \pm \text { SD) }\end{array}$ \\
\hline Side Steps & $11.03 \pm 0.84$ & $9.74 \pm 0.71$ & $11.68 \pm 0.96$ & $12.02 \pm 1.16$ \\
20 Steps forward Twirling a Baton & $12.02 \pm 1.85$ & $10.73 \pm 1.58$ & $15.02 \pm 2.82$ & $14.16 \pm 2.52$ \\
Skipping the Horizontal Jump Rope & $16.33 \pm 6.44$ & $18.63 \pm 5.86$ & $14.18 \pm 7.19$ & $15.11 \pm 6.67$ \\
Turning in 6 Squares & $5.33 \pm 1.90$ & $7.74 \pm 1.31$ & $3.96 \pm 1.19$ & $4.96 \pm 1.48$ \\
Hand-Foot Drumming & $9.14 \pm 2.03$ & $12.59 \pm 2.18$ & $8.81 \pm 2.11$ & $9.00 \pm 1.79$ \\
Agility test with a Baton & $7.01 \pm 1.43$ & $6.75 \pm 1.82$ & $7.03 \pm 1.18$ & $7.28 \pm 1.24$ \\
SJ & $20.85 \pm 4.35$ & $23.65 \pm 4.58$ & $18.97 \pm 2.66$ & $20.91 \pm 3.51$ \\
CMJ & $22.50 \pm 4.21$ & $25.47 \pm 4.95$ & $20.75 \pm 3.84$ & $22.61 \pm 3.92$ \\
\hline
\end{tabular}

The results of the multivariate analysis of variance at the initial measurement (Table 3) showed that there was a statistically significant difference in the coordination parameters between the experimental and control participants at the multivariate level $(\mathrm{p}=.002)$.

Analysis of the results of the univariate analysis of variance (Table 3) revealed that the experimental group of participants achieved better results in all coordination parameters, with the variables Side Steps $(\mathrm{p}=.011), 20$ Steps forward Twirling a Baton $(\mathrm{p}=.000)$ and Turning in 6 Squares $(\mathrm{p}=.003)$ were statistically significant, while for the other variables a numerical difference was observed in favor of the experimental group. It can be stated that the participants of the experimental group had better coordination skills at the initial measurement.

Table 3 Results of the ANOVA and MANOVA of coordination at the initial and final measurement between the experimental (EG) and control group (CG)

\begin{tabular}{|c|c|c|c|c|c|c|c|c|}
\hline \multirow[t]{2}{*}{ Variables } & \multicolumn{2}{|c|}{ Initial } & \multicolumn{6}{|c|}{ Final } \\
\hline & $\begin{array}{c}\text { EG } \\
\text { Mean+SD }\end{array}$ & $\begin{array}{c}\text { CG } \\
\text { Mean+SD }\end{array}$ & $\mathrm{F}$ & $\mathrm{p}$ & $\begin{array}{c}\text { EG } \\
\text { Mean+SD }\end{array}$ & $\begin{array}{c}\text { CG } \\
\text { Mean+SD }\end{array}$ & $\mathrm{F}$ & $\mathrm{p}$ \\
\hline Side Steps & 11.03 & 11.69 & 7.023 & $.011^{*}$ & 9.74 & 12.02 & 75.805 & $.000^{* *}$ \\
\hline $\begin{array}{l}20 \text { Steps forward } \\
\text { Twirling a Baton }\end{array}$ & 12.02 & 15.03 & 21.327 & $.000^{* *}$ & 10.73 & 14.16 & 35.691 & $.000^{* * *}$ \\
\hline $\begin{array}{l}\text { Skipping the Horizontal } \\
\text { Jump Rope }\end{array}$ & 16.33 & 14.19 & 1.335 & .253 & 18.63 & 15.11 & 4.237 & $.045^{*}$ \\
\hline Turning in 6 squares & 5.33 & 3.96 & 10.066 & $.003^{* *}$ & 7.74 & 4.96 & 53.028 & $.000^{* *}$ \\
\hline $\begin{array}{l}\text { Hand - Foot } \\
\text { Drumming }\end{array}$ & 9.15 & 8.81 & .349 & .557 & 12.59 & 9.00 & 43.452 & $.000^{* * *}$ \\
\hline $\begin{array}{l}\text { Agility test with a } \\
\text { Baton }\end{array}$ & 7.02 & 7.03 & .001 & .974 & 6.75 & 7.28 & .673 & .416 \\
\hline & Wilk's & $52 \mathrm{~F}=4$ & $4 \mathrm{p}=$ & & Wilk's & $308 \mathrm{~F}=17$. & $1 \mathrm{p}=.0$ & \\
\hline
\end{tabular}

The results of the multivariate analysis of variance of explosive power at the initial measurement (Table 4) showed that there was no statistically significant difference at the multivariate level between the participants of the experimental and control groups. 
By examining the results at the univariate level (Table 4), we found that there was a numerical difference in favor of the experimental group, but that it was not sufficient to be statistically significant. Based on these results, it can be concluded that the experimental and control participants were approximately at the same level of explosive power at the initial measurement.

Table 4 Results of the ANOVA and MANOVA of explosive power at the initial and final measurement between the experimental (EG) and control group (CG)

\begin{tabular}{lcccccccc}
\hline \multirow{2}{*}{ Variables } & \multicolumn{2}{c}{ Initial } & \multicolumn{5}{c}{ Final } \\
\cline { 2 - 9 } & $\begin{array}{c}\text { EG } \\
\text { Mean+SD }\end{array}$ & $\begin{array}{c}\text { CG } \\
\text { Mean+SD }\end{array}$ & F & p & $\begin{array}{c}\text { EG } \\
\text { Mean+SD }\end{array}$ & $\begin{array}{c}\text { CG } \\
\text { Mean+SD }\end{array}$ & F & p \\
\hline Squat Jump & 20.85 & 18.97 & 3.691 & .060 & 23.65 & 20.91 & 6.046 & $.017^{*}$ \\
Countermovement Jump & 22.50 & 20.75 & 2.532 & .118 & 25.47 & 22.61 & 5.556 & $.022^{*}$ \\
\hline \multicolumn{1}{l}{ Wilk's=.934 F=1.810 p=.174 } & Wilk's=.895 F=3.004 p=.058 \\
\hline
\end{tabular}

The differences between the initial and final measurements for all the parameters were calculated on the basis of the t-test for dependent samples while calculating the degree of the differences (Cohen's d). The criterion for determining the degree of the impact (Effect Size) was: .01=small effect size; .06=intermediate effect size; $.14=$ large effect size.

According to the data in Graph 1, it was observed that the experimental group of participants improved their results on the final measurement in the coordination parameters, and that statistically significant differences were observed for all the variables except the Agility test with a Baton ( $\mathrm{p}=.412)$, for which an improvement was observed in the results, but not enough to make this difference statistically significant. Also, the influence of the experimental treatment on the changes in coordination parameters is large, which is shown by the degree of the influence of all statistically significant variables that are over .14.

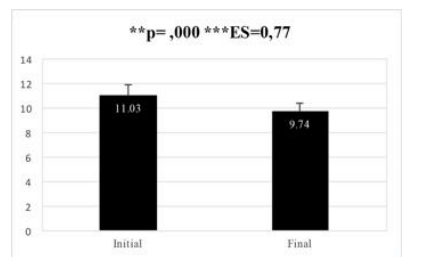

Side Steps

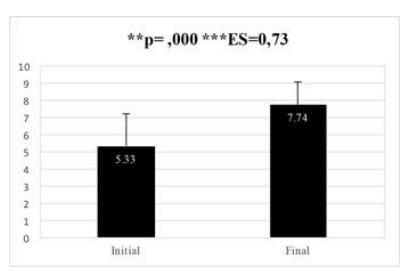

Turning in 6 Squares

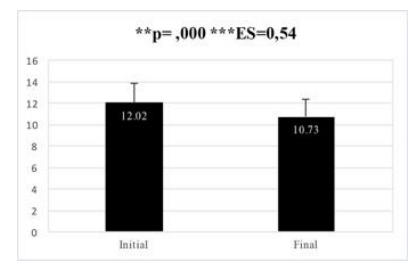

20 Steps forward Twirling a Baton

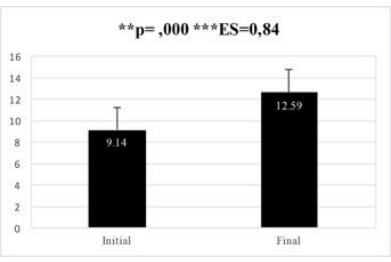

Hand - Foot Drumming

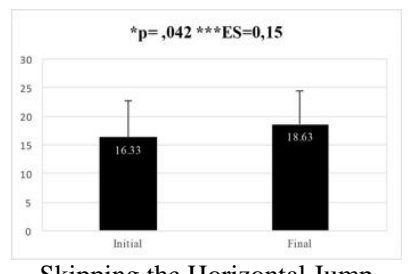

Skipping the Horizontal Jump Rope $\mathrm{p}=, \mathbf{4 1 2}$ *ES=0,03

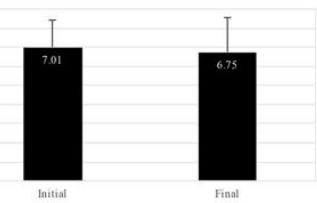

Agility Test with a Baton

Graph 1 Effect size of coordination (experimental group) Legend: ${ }^{*} \mathrm{p}<.05,{ }^{* *} \mathrm{p}<.01$; ES-Effect Size ${ }^{*} .01=$ small effect size, ${ }^{* *} .06=$ Intermediate effect size, ${ }^{* * *} .14=$ Large effect size 
In Graph 2, the t-test results show that for both variables estimating the explosive power of $\mathrm{SJ}(\mathrm{p}=.000)$ and $\mathrm{CMJ}(\mathrm{p}=.000)$ there is statistical significance at the .01 level. Effect size results for the explosive power parameters indicate that the 10-week experimental exercise program had a large effect size on both variables for estimating explosive power: $\mathrm{SJ}(\mathrm{ES}=.51)$ and $\mathrm{CMJ}(\mathrm{ES}=.57)$.

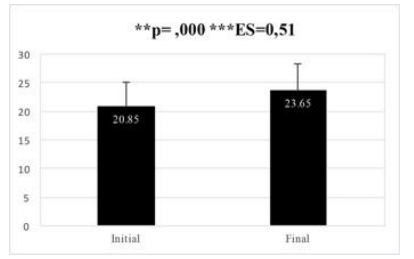

Squat Jump

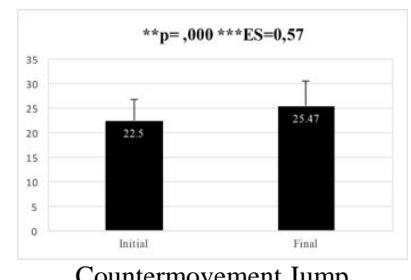

Countermovement Jump

Graph 2 Effect size of explosive power (experimental group)

Legend: ${ }^{*} \mathrm{p}<0.05,{ }^{* *} \mathrm{p}<0.01$;

ES - Effect Size ${ }^{*} 0.01=$ small effect size, ${ }^{* *} 0.06=$ Intermediate effect size, ${ }^{* * *} 0.14=$ Large effect size

The results of the multivariate analysis of variance at the final measurement between the EG and CG participants (Table 3) in the coordination parameters revealed that there was a statistically significant difference between the groups at the .01 level $(p=.000)$. At the univariate level, a statistically significant difference was also found for all variables except the Agility test with a Baton $(\mathrm{p}=.416)$. The Side Steps $(\mathrm{p}=.000), 20$ Steps forward Twirling a Baton $(\mathrm{p}=.000)$, Turning in 6 Squares $(\mathrm{p}=.000)$ and Hand-Foot Drumming $(\mathrm{p}=.000)$ variables were statistically significant at the .01 level, while the Skipping the Horizontal Jump Rope variable ( $\mathrm{p}=.045)$ had statistical significance at the .05 level (Table 3 ).

Based on the results of the multivariate analysis of variance between the experimental and control participants on the final measurement (Table 4), it was found that the intergroup differences were within the scope of statistical significance $(\mathrm{p}=.058)$. At the univariate level, the results showed that the participants of the experimental group achieved better results, and that there was a statistically significant difference between the SJ variable $(p=.017)$ and the CMJ variable $(\mathrm{p}=.022)$ at the level of statistical significance of .05 (Table 4).

\section{DISCUSSION}

While comparing the EG and CG at the initial measurement, it was found that the participants of the experimental group had better coordination abilities. Similar results were observed in the studies of Uzunovic (2009) and Miljkovac (2015), where the experimental group of participatns performed better in the Side Steps and Hand-Foot Drumming tests, while there were no statistically significant differences in the other variables. There were no statistically significant differences in the parameters for the estimation of explosive power between the experimental and control groups at the initial measurement, which coincides with the results of Koutedakis et al. (2007).

The results of this study indicate that after the implementation of a ten-week exercise program of modern Hip Hop and Dancehall dances, there was an improvement in the coordination parameters of the experimental group. The results between the experimental and control groups at the final measurement showed that the experimental group was 
better, and that a statistically significant difference was found in all the estimated coordination parameters, except for the Agility test with a Baton. Similar results were obtained by ViskićŠtalec, Štalec, Katić, Podvorac, \& Katović (2007) who noted the positive impact of an experimental program based on dance, aerobics and rhythmic gymnastics on the parameters of coordination and agility. A large influence of the experimental treatment was observed in the Turning in 6 squares and Hand-Foot Drumming variables. For their realization, it is necessary to have a pronounced coordination in rhythm because it is essential to harmonize the movement of the body with the given rhythm of the metronome, which is a basic prerequisite for successful performance of Hip Hop and Dancehall (Su, 2016). In order to perform this, dancers must have a developed sensorimotor synchronization (SMS) which represents the coordination of rhythmic movements with an external rhythm or beat (Repp, 2005). Dance training facilitates SMS (Karpati, Giacosa, Foster, Penhune, \& Hyde, 2016) and allows dancers to have more accurate and stable SMS than non-dancers (Jin et al., 2019), which is particularly expressed in Street Dancing (Miura, Fujii, Okano, Kudo, \& Nakazawa, 2016). The specific technique and movement structures of modern dances imply a large number of rapid changes of direction and weight transfer, harmonization of movements to the rhythm of music, and coordination of movements with other dancers on the dance floor. The technique of certain figures is very similar to test movements such as Side Steps 20 Steps forward Twirling a Baton, therefore it is expected that the results will be improved with these variables. Lateral movement and step-step is common in modern dances, while stepping back with rapid weight transfer and returning to the starting position is one of the basic movements in Dancehall. Constant repetition of these movements and techniques can contribute to the transformation of certain indicators of coordination, which is in line with the results of Uzunović (2008), who recorded an improvement in the results of certain tests of 20 Steps forward Twirling a Baton, Skipping the Horizontal Jump Rope, Turning in 6 Squares and Hand-Foot Drumming after applying a program of modern sports dance.

The results of the parameters for the estimation of explosive power showed significant progress between the two tests. In this study, additional exercises were performed to strengthen the muscles of the torso and legs with their own load, the volume and intensity of the exercises being similar to the recommendations of Koutedakis, Clarke, Wyon, Aways, \& Owolabi (2009). The participants of the experimental group recorded an increase in jump height of $13.4 \%$ for SJ and $13.2 \%$ for CMJ. These results are in agreement with the study of Brown et al. (2007) who reported a slight improvement in the jump height of $8.3 \%$ for the plyometric training group, and $3.76 \%$ for the traditional load training group. In the study, the duration of the experimental treatment was shorter. Dowse, McGuigan, \& Harrison (2017) showed the smallest improvement in jump height after exercise training, with a jump height increase of $4.5 \%$ for SJ, and $3.2 \%$ for $\mathrm{CMJ}$, while similar results were reported by Stalder, Noble, \& Wilkinson (1990). Vibration training has also proven to be an effective means of improving the parameters of explosive power in dance. Annino et al. (2007) reported a 6.3\% improvement in CMJ values in a sample of elite ballerinas, while Marshal \& Wyon (2012) and Wyon, Guinan, \& Hawkey (2010) confirmed that vibration training could also be used as an effective training tool to increase explosive power in dancers. The exercise program used in this research has led to greater improvements in jump height than in other studies, indicating that the additional strength exercises involved in dance training can effectively increase the explosive power. At the final measurement, a statistically significant difference was found between the participants of the experimental and control group for both explosive power variables at the univariate level, with the 
participants of the experimental group achieving better results than the control group. The results obtained are in contrast to the study of Harley et al. (2002) where dancers generated greater force during the isometric contraction of quadriceps but did not record higher values of vertical jump. Also, in the study of Bennell et al. (1999) the control group had greater flexor, adductor, and internal and external hip rotator muscle strength relative to dancers, indicating the importance of additional strength training in dancers. Strength training in dancers should be focused not only on muscle training, but also on nerve path training. By training the proper nerve pathways, dancers are able to activate a greater proportion of their musculature while performing dance movements (Koutedakis et al., 2009). In the realized program, a combination of leg and trunk muscles exercises and plyometric exercises was applied. Combining strength exercises such as squats with fast and explosive movements stimulates the neuromuscular system more effectively (Ebben \& Watts, 1998), while plyometric training increases muscle strength of the torso and leg flexors and improves the activation of more motor units (Adams, O'Shea, O'Shea, $\&$ Climstein, 1992). Strength training was used in this research as an additional form of exercise along with the dance part of the training.

\section{CONCLUSION}

The results of the research showed that a ten-week exercise program for recreational and modern dance and exercises for strengthening the muscles of the torso and legs have a positive effect on changes in the parameters of coordination and explosive power in studentage female dancers. The use of Hip Hop and Dancehall as a fun form of physical exercise can influence the development of coordination skills by performing and repeating specific dance movements and figures, while the exercises to strengthen the trunk and leg muscles provide additional training stimulus that is lacking in conventional forms of dance training without additional exercises.

Future research should focus on a more appropriate examination of the impact of these dances on other motor skills, as well as on other components of physical fitness.

\section{REFERENCES}

Adams, K., O'Shea, J.P., O'Shea, K,L., \& Climstein, M. (1992). The effect of six week of squat, plyometric and squat-plyometric training on power production. Journal of Applied Sport Science Research, 6 (1), 36-41.

Annino, G., Padua, E., Castagna, C., Di Salvo, V., Minichella S., Tsarpela, O., et al. (2007). Effect of whole body vibration training on lower limb performance in selected high-level ballet students. Journal of Strength and Conditioning Research, 21 (4), 1072-1076.

Bennell, K., Khan, K.M., Matthews, B., De Gruyter, M., Cook, E., Holzer, K., et al. (1999). Hip and ankle range of motion and hip muscle strength in young female ballet dancers and controls. British Journal of Sports Medicine, 33 (5), 340-346.

Brown, A.C., Wells, T.J., Schade, M.L., Smith, D.L., \& Fehling, P.C. (2007). Effects of plyometric training versus traditional weight training on strength, power, and aesthetic jumping ability in female collegiate dancers. Journal of Dance Medicine \& Science, 11 (2), 38-44.

Cohen, J. (1988). Statistical power analysis for the behavioral sciences (2nd ed.). Hillsdale, NJ: Erlbaum

Dowse, R.A., McGuigan, M.R., \& Harrison, C. (2017). Effects of a resistance training intervention on strength, power, and performance in adolescent dancers. Journal of Strength and Conditioning Research, Nov 1. doi: 10.1519/JSC.0000000000002288.

Ebben, W.P., \& Watts, P.B. (1998). A review of combined weight training and plyometric training modes: Complex training. Journal of Strength and Conditioning Research, 20 (5), 18-27. 
Harley, Y., Gibson, A., Harley, E.H., Lambert, M., Vaughan, C., \& Noakes, T.D. (2002). Quadriceps strength and jumping efficiency in dancers. Journal of Dance Medicine \& Science, 6 (3), 87-94.

Jarvis, D.N., Smith, J.A., \& Kulig, K. (2014). Trunk coordination in dancers and nondancers. Journal of Applied Biomechanics, 30 (4), 547-554.

Hošek, A., Horga, S., Viskić-Štalec, N., Metikoš, M., Gredelj, M., \& Marčelja, D. (1973). Metrijske karakteristike za procjenu faktora koordinacije u ritmu (Metric characteristics for the estimation of coordination factors in rhythm). Kineziologija, 3 (2), 37-45. In Croatian.

Jin, X., Wang, B., Lv, Y., Lu, Y., Chen, J., \& Zhou, C. (2019). Does dance training influence beat sensorimotor synchronization? Differences in finger-Tapping sensorimotor synchronization between competitive ballroom dancers and nondancers. Experimental Brain Research, 237 (3), 743-753.

Karpati, F.J., Giacosa, C., Foster, N.E., Penhune, V.B., \& Hyde, K.L. (2016). Sensorimotor integration is enhanced in dancers and musicians. Experimental Brain Research, 234 (3), 893-903.

Kiefer, A.W., Riley, M.A., Shockley, K., Sitton, C.A., Hewett, T., Cummins-Sebree, S., et al. (2011). Multisegmental postural coordination in professional ballet dancers. Gait \& Posture, 34 (1), 76-80.

Kirkendal, D.T., \& Calabrese, L. H. (1983). Physiological aspect of dance. Clinics in Sports Medicine, 2(3), 525-537.

Kostić, R. (1995). Metrijske karakteristike mernih instrumenata za procenu sposobnosti izvođenja ritmičkih struktura (Metric characteristics of measuring instruments for evaluating the ability to perform rhythmic structures). Book of Proceedings "Fis Communications 1995", (pp. 103-107). Niš: Faculty of Philosophy, Department of Physical Culture. In Serbian

Koutedakis, Y., \& Sharp, N.C.C. (2004). Thigh muscles strength training, dance exercise, dynamometry, and anthropometry in professional ballerinas. Journal of Strength and Conditioning Research, 18 (4), 714-718.

Koutedakis, Y., Hukam, H., Metsios, G., Nevill, A., Giakas, G., Jamurtas, A., et al. (2007). The effect of three months aerobic and strength training on selected performance-and fitness-related parameters in modern dance students. Journal of Strength and Conditioning Research, 21 (3), 808-812.

Koutedakis, Y., Clarke, F., Wyon, M., Aways, D., \& Owolabi, E.O. (2009). Muscular strength: Application for dancers. Medical Problems of Performing Artists, 24 (4), 157-165.

Kurelić, N., Momirović, K., Stojanović, M., Šturm, J., Radojević, Đ., \& Viskić-Štalec, N. (1975). Struktura i razvoj morfoloških $i$ motoričkih dimenzija omladine (Structure and development of morphological and motor dimensions of youth). Belgrade: Institute for Scientific Research, Faculty of Physical Education, University of Belgrade. In Serbian

Liiv, H., Jurimae, T., Maestu, J., Purge, P., Hannus, A., \& Jurimae, J. (2012). Physiological characteristics of elite dancers of different dance styles. European Journal of Sport Science, 14, s429-s436.

Macura, M., Pešić, K., Đorđević-Nikić, M., Stojiljković, S., \& Dabović, M. (2007). Morphological characteristics and functional abilities of an elite folk ensemble dancer. Physical Culture, 61, 105-111.

Marshall, L.C., \& Wyon, M.A. (2012). The effect of whole-body vibration on jump height and active range of movement in female dancers. Journal of Strength and Conditioning Research, 26 (3), 789-793.

Marčelja, D., Hošek, A., Viskić-Štalec, N., Horga, S., Gredelj, M., \& Metikoš, D. (1973). Metrijske karakteristike za procjenu faktora koordinacije tijela (Metric characteristics for the evaluation of body coordination factors). Kineziologija, 3 (2), 5-13. In Croatian

Metikoš, D., Prot, F., Hofman, E., Pintar, Ž., \& Oreb, G. (1989). Mjerenje bazičnih motoričkih sposobnosti sportaša (Measurement of basic motor skills of athletes). Zagreb: Fakultet fizičke kulture Sveučilišta $\mathrm{u}$ Zagrebu. Faculty of Physical Culture, University of Zagreb. In Croatian

Metikoš, D., Marković, G., Prot, F., \& Jukić, I. (2003). Latent structure of agility obtained by a batery of tests. Kinesiology, 35 (1), 14-29.

Miura, A., Fujii, S., Okano, M., Kudo, K., \& Nakazawa, K. (2016). Finger-to-beat coordination skill of nondancers, street dancers, and the World Champion of a street-dance-competition. Frontiers in Physiology, 7, 542.

Miljkovac, Z. (2015). Uticaj različitih vrsta plesova na koordinaciju u ritmu i muzikalnost (The influence of different types of dances on coordination in rhythm and musicality). Master Thesis. Belgrade: Faculty of Sport and Physical Education, University of Belgrade. In Serbian

Pepper, M.S. (1984). Dance-a suitable form of exercise?. South African Medical Journal, 66, 883-888.

Repp, B.H. (2005). Sensorimotor synchronization: A review of the tapping literature. Psychonomic Bulletin \& Review, 12 (6), 969-992.

Rimmer, J.H., Jay, D., \& Plowman, S.A. (1994). Physiological characteristics of trained dancers and intensity level of ballet class and rehearsal. Impulse, 2 (2), 97-105.

Rodrigues-Krause, J., Krause, M., Cunha, G.D., Perin, D., Martins, J.B., Alberton, C., et al. (2014). Ballet dancers cardiorespiratory, oxidative and muscle damage responses to classes and rehearsals. European Journal of Sport Science, 14 (3), 199-208. 
Slddlque, U., Rahman, S., Frazer, A.K., Howatson, G., \& Kidgell, D.J. (2019). Determining the sites of neural adaptations to resistance training: a systematic review and meta-analysis. Sports Medicine, Jul 29. DOI: 10.1007/s40279-019-01152-3.

Stalder, M.A., Noble, B.J., \& Wilkinson, J.G. (1990). The effects of supplemental weight training for ballet dancers. The Journal of Applied Sport Science Research, 4 (3), 95-102.

Stošić, D., Uzunović, S., Kostić, R., Ljubojević, A., \& Marković, J. (2013). The canonical correlation of coordination and other anthorpomotirical abilities of the dancers of the modern dance "Disco Dance". In S. Pantelić (Ed.), Book of Proceedings"Fis Communications 2013”, (pp. 115-122). Niš: Faculty of Sport and Physical Education, University of Niš.

$\mathrm{Su}$, Y.H. (2016). Visual tuning and metrical perception of realistic point-light dance movements. Scientific Reports, 7 (6), $1-12$

Uzunović, S. (2008). The transformation of strength, speed and coordination under the influence of sport dancing. Facta Universitatis Series Physical Education and Sport, 6 (2), 135-146.

Uzunović, S. (2009). Efekti eksperimentalnog programa modernog sportskog plesa na promene motoričke koordinacije, snage i brzine (Effects of an experimental program of modern sports dance on changes in motor coordination, power and speed). PhD Thesis. Niš: Faculty of Sport and Physical Education, University of Niš. In Serbian

Vetter, R.E., \& Dorgo, S. (2009). Effects of partner's improvisational resistance training on dancers' muscular strength. Journal of Strength and Conditioning Research, 23 (3), 718-728.

Viskić-Štalec, N., Štalec, J., Katić, R., Podvorac, Đ., \& Katović, D. (2007). The impact of dance-aerobics training on the morpho-motor status in female high schoolers. Collegium Antropologicum, 31 (1), 259-66.

Wyon, M., \& Redding, E. (2005). Physiological monitoring of cardiorespiratory adaptations during rehearsal and performance of contemporaray dance. Journal of Strength and Conditioning Research, 19 (3), 611-614.

Wyon, M., Guinan, D., \& Hawkey, A. (2010). Whole body vibration training increases vertical jump height in a dance population. Journal of Strength and Conditioning Research, 24 (3), 866-870.

\section{UTICAJI PROGRAMA VEŽBANJA NA KOORDINACIJU I EKSPLOZIVNU SNAGU UNIVERZITETSKIH STUDENATA PLESA}

Cilj ovog istraživanja je da se utvrde efekti programa vežbanja modernog i rekreativnog plesa $i$ vežbi jačanja mišića trupa i nogu na koordinaciju i eksplozivnu snagu plesača studentskog uzrasta. Ukupan uzorak činilo je 54 ispitanica, od čega je 27 ispitanica bilo podeljeno u eksperimentalnu grupu koja je primenjivala eksperimentalni program vežbanja $i 27$ ispitanica kontrolne grupe. Eksperimentalna grupa izvodila je časove Hip Hop-a i Dancehall-a kao i vežbe za jačanje mišića trupa i nogu, tri puta nedeljno po 90 minuta. Kontrolna grupa nije primenjivala nikakve dodatne oblike vežbanja. Koordinacija je procenjena na osnovu 6 testova (Koraci u stranu, 20 iskoraka provlačenjem palice, Preskakanje horizontalne vijače, Okreti u 6 kvadrata i Test okretnosti sa palicom) i na osnovu 2 testa za procenu eksplozivne snage (Squat Jump i Countermovement Jump).Rezultati su pokazali statistički značajne razlike između grupa na finalnom merenju kod 5 varijabli koordinacije na multivarijantnom $i$ univarijantnom nivou $(p<0.05, p<0.01) i$ kod obe varijable eksplozivne snage $(p<0.05)$ na univarijantnom nivou. Velika i srednja veličina uticaja eksperimentalnog programa utvrđena je kod 5 varijabli koordinacije, dok je umerena veličina uticaja utvrđena kod obe varijable eksplozivne snage. Rezultati istraživanja su pokazali da desetonedeljni program vežbanja rekreativnog i modernog plesa $i$ vežbi za jačanje mišića trupa $i$ nogu pozitivno utiče na koordinaciju i eksplozivnu snagu kod plesačica studentskog uzrasta.

Ključne reči: koordinacija, eksplozivna snaga, rekreacija, moderni plesovi 